\title{
South Georgia blue whales five decades after the end of whaling
}

\author{
Susannah V. Calderan ${ }^{1, *}$, Andy Black ${ }^{2}$, Trevor A. Branch ${ }^{3}$, Martin A. Collins ${ }^{4}$, \\ Natalie Kelly ${ }^{5}$, Russell Leaper ${ }^{6}$, Sarah Lurcock ${ }^{7}$, Brian S. Miller ${ }^{5}$, Michael Moore ${ }^{8}$, \\ Paula A. Olson ${ }^{9}$, Ana Širović ${ }^{10}$, Andrew G. Wood ${ }^{4}$, Jennifer A. Jackson ${ }^{4}$ \\ ${ }^{1}$ Scottish Association for Marine Science (SAMS), Argyll PA37 1QA, UK \\ ${ }^{2}$ Government of South Georgia and South Sandwich Islands, Government House, Stanley FIQQ 1ZZ, Falkland Islands \\ ${ }^{3}$ School of Aquatic and Fishery Sciences, University of Washington, Seattle, WA 98195, USA \\ ${ }^{4}$ British Antarctic Survey, NERC, High Cross, Cambridge CB3 0ET, UK \\ ${ }^{5}$ Australian Antarctic Division, Department of Agriculture, Water and the Environment, Kingston, Tasmania 7050, Australia \\ ${ }^{6}$ International Fund for Animal Welfare, London SE1 8NL, UK \\ ${ }^{7}$ South Georgia Heritage Trust, Dundee DD1 5BT, UK \\ ${ }^{8}$ Woods Hole Oceanographic Institution, Woods Hole, MA 02543, USA \\ ${ }^{9}$ Southwest Fisheries Science Center, NMFS/NOAA, La Jolla, CA 92037, USA \\ ${ }^{10}$ Texas A\&M University at Galveston, Galveston, TX 77553, USA
}

\begin{abstract}
Blue whales Balaenoptera musculus at South Georgia were heavily exploited during $20^{\text {th }}$ century industrial whaling, to the point of local near-extirpation. Although legal whaling for blue whales ceased in the 1960s, and there were indications of blue whale recovery across the wider Southern Ocean area, blue whales were seldom seen in South Georgia waters in subsequent years. We collated $30 \mathrm{yr}$ of data comprising opportunistic sightings, systematic visual and acoustic surveys and photo-identification to assess the current distribution of blue whales in the waters surrounding South Georgia. Over $34000 \mathrm{~km}$ of systematic survey data between 1998 and 2018 resulted in only a single blue whale sighting, although opportunistic sightings were reported over that time period. However, since 2018 there have been increases in both sightings of blue whales and detections of their vocalisations. A survey in 2020 comprising visual line transect surveys and directional frequency analysis and recording (DIFAR) sonobuoy deployments resulted in 58 blue whale sightings from $2430 \mathrm{~km}$ of visual effort, including the photo-identification of 23 individual blue whales. Blue whale vocalisations were detected on all 31 sonobuoys deployed $(114 \mathrm{~h})$. In total, 41 blue whales were photo-identified from South Georgia between 2011 and 2020, none of which matched the 517 whales in the current Antarctic catalogue. These recent data suggest that blue whales have started to return to South Georgia waters, but continued visual and acoustic surveys are required to monitor any future changes in their distribution and abundance.
\end{abstract}

KEY WORDS: Blue whale $\cdot$ Balaenoptera musculus $\cdot$ South Georgia $\cdot$ Recovery $\cdot$ Whaling Southern Ocean

\section{INTRODUCTION}

Before the onset of industrial whaling in the Southern Ocean, there was perhaps nowhere in the world more densely populated with large whales than South Georgia (Richardson et al. 2012). The island, situated in the Atlantic Sector of the Southern Ocean to the south of the Polar Front, has a marine ecosys-

\footnotetext{
${ }^{*}$ Corresponding author: susannah.calderan@sams.ac.uk
}

tem which is known for its high biodiversity (Hogg et al. 2011) and productivity (Atkinson et al. 2001, Murphy et al. 2004). Local biomass of Antarctic krill Euphausia superba and copepods are very high relative to typical values for Antarctica (Atkinson et al. 2001). It is an important feeding ground for seabirds, pinnipeds, whales and other marine predators, and supports a fishery for krill (Kemp \& Bennett 1932,

(C) The authors 2020. Open Access under Creative Commons by Attribution Licence. Use, distribution and reproduction are unrestricted. Authors and original publication must be credited. 
Leaper et al. 2006, Tarling et al. 2012, Fielding et al. 2014, Trathan et al. 2014). When industrial whaling began in the early $20^{\text {th }}$ century, South Georgia was the first place in the Southern Ocean to be targeted.

The first Southern Ocean shore-based whaling station was established by the Norwegian Carl Anton Larsen at Grytviken, South Georgia, in 1904, marking the onset of industrial whaling in the Southern Ocean. By 1912, 7 shore-based whaling stations were running on the island. Whaling operations focussed first on species which were easily caught and/or were the most valuable (Fig. 1). The first species to be hunted to commercial extinction at South Georgia was the humpback whale Megaptera novaeangliae, southern right whales Eubalaena australis

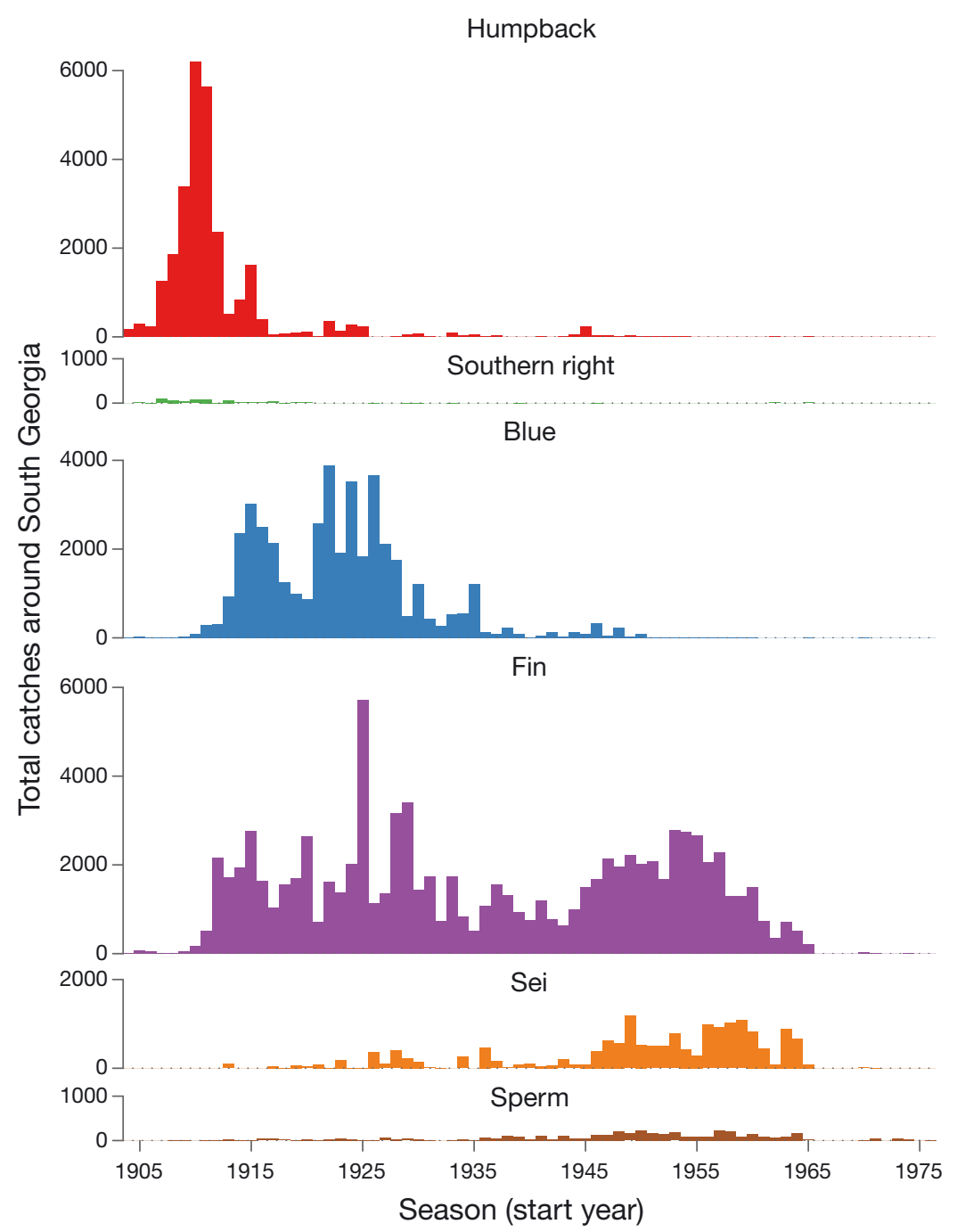

Fig. 1. All blue whale catches taken from land stations at South Georgia, together with pelagic catches within $52-57^{\circ} \mathrm{S}, 43.5-32.5^{\circ} \mathrm{W}$. In addition, a single Antarctic minke was caught, and 43 catches did not specify the species having already been heavily depleted by whaling at lower latitudes before industrial whaling had begun (Moore et al. 1999, Richardson et al. 2012).

From 1913, focus moved to blue whales Balaenoptera musculus. Until the start of industrial whaling, there had been no widespread whaling of either blue whales or fin whales $B$. physalus, but steampowered catcher vessels and explosive harpoons made catching these species possible. In the Southern Hemisphere and the northern Indian Ocean, 345775 Antarctic blue whales B. m. intermedia and 13022 pygmy blue whales $B$. m. brevicauda were killed between 1904 and 1973 (Branch et al. 2008). In the years between 1921 and 1935, blue whales were the main species caught in the Southern Hemisphere (except for 1925), with a peak of 30406 blue whales killed in the 1930/1931 austral summer season (Branch et al. 2008).

At South Georgia, blue whales were present year-round, and catches were reported in every month of the year (Branch et al. 2007b). Catches were overwhelmingly Antarctic blue whales, but may have included a few Southeast Pacific blue whales (Branch 2020) or even pygmy blue whales (Branch et al. 2007a) based on length frequency data, although early South Georgia catch length data were unreliable. In many seasons, over 3000 blue whales were killed; the season with the highest catch (3689 animals) was 1926/1927 (Clapham et al. 2008). In the late 1920s, as shore-based whaling at South Georgia declined due to intensive exploitation, pelagic whaling from factory ships commenced. These ships could range much further afield on the high seas, and would use South Georgia as a base for repair, maintenance and storage (Vamplew 1975). By the early 1930s, there were signs of blue and fin whale population collapse at South Georgia. Kemp \& Bennett (1932, p. 179) noted that

... the considerable extension of the grounds during the recent four-year period, and the fact that with the same number of whale-catchers fewer whales have been taken, lends support to the generally held opinion that whales are now less abundant than formerly ...

By 1935, blue whales had already been depleted to the extent that they 
were no longer the primary target species (Clapham et al. 2008, Rocha et al. 2014). However, exploitation continued opportunistically whenever blue whales were encountered whilst hunting for fin whales and other species, continuing the drive towards extinction (Branch et al. 2013). Fewer than 1800 of the total catch of 42698 blue whales at South Georgia between the 1904/1905 and 1970/1971 seasons were taken after the 1936/1937 season (Fig. 1). Within the South Georgia area, just 359 blue whales were taken by the pelagic fleet, less than $1 \%$ of the total. In the early 1900 s, South Georgia waters thronged with blue whales; within little over $30 \mathrm{yr}$, they were all but gone.

South Georgia was part of a hemisphere-wide nearextirpation of Antarctic blue whales, so repopulation from a wider area after whaling ceased could not readily occur; the few decades of industrial whaling in the Southern Ocean had reduced Antarctic blue whales to $0.15 \%$ of their estimated pre-exploitation abundance (Branch et al. 2004). The International Whaling Commission International Decade of Cetacean Research / Southern Ocean Whale and Ecosystem Research Programme (IDCR-SOWER) cruises, which took place across the wider Southern Ocean (with negligible effort around South Georgia) from 1978 to 2010, found increases in Antarctic blue whale abundance (Branch et al. 2004), and estimated recovery to around $1 \%$ of pre-whaling levels by 1998 (Branch 2007). However, in the localised area around South Georgia, blue whales appeared to be even less abundant and, although there was little in the way of other systematic surveys for whales through the 3 decades following the end of whaling, blue whales were very rarely reported (Moore et al. 1999, Richardson et al. 2012). There appeared to be little or no local remnant population, and insufficient animals in adjacent areas to allow immigration and redistribution of animals from the wider Antarctic population.

The extreme depletion of blue whales may also have resulted in a loss of cultural knowledge of the habitat as a feeding area, which in many whale species is transmitted through maternally directed learning and fidelity to important habitats (Clapham et al. 2008, Baker et al. 2013, Carroll et al. 2015). When the whales were removed from South Georgia, the cultural memory of the area may have been erased. Whaling for blue whales at South Georgia has been cited as an example of how it is possible to exploit a local population beyond the point of recovery (Clapham et al. 2008).

Blue whales were not the only marine mammal taxon to be heavily exploited at South Georgia. In addition to $20^{\text {th }}$ century whaling on other large whales, sealing for Antarctic fur seals Arctocephalus gazella in South Georgia in the late $18^{\text {th }}$ and early $19^{\text {th }}$ century was characterised by

uncontrolled exploitation leading to the near extermination of the animals concerned

(Bonner 1958, p. 379). However, although the status of Antarctic fur seals had been very poor throughout most of South Georgia from the early $19^{\text {th }}$ to the early $20^{\text {th }}$ century, by the $1940 \mathrm{~s}$, the population had started to recolonise from animals which had been left in the northwestern extremities of South Georgia and around Bird and Willis Islands (Bonner 1958, 1968). Although there is no recent agreed abundance estimate, the population has now substantially recovered and is considered once more to play a functional role in the South Georgia ecosystem (Foley \& Lynch 2020). Once the fur seals were gone, attention moved to killing southern elephant seals Mirounga leonina, which were also heavily exploited in the first half of the $20^{\text {th }}$ century; this species too recovered significantly once exploitation ceased (Boyd et al. 1996).

Globally, marine mammal population recoveries from exploitation that resulted in local extinction have been patchy and influenced by a number of factors (Clapham et al. 2008). These include the abundance and demographics of a remnant and/or surrounding population, but also the continued presence or introduction of other anthropogenic threats such as ongoing deliberate killing, fisheries bycatch, ship strikes, reduced food availability and pollution, or several of these factors combined (Corkeron et al. 2018).

At South Georgia, whale mortality was due entirely to whaling, in what is otherwise a favourable whale habitat with abundant food and low levels of anthropogenic threats. However, until very recently, visual whale surveys found almost no blue whales around South Georgia (Moore et al. 1999, Širović et al. 2006, Rossi-Santos et al. 2007).

In addition to visual surveys, there have also been acoustic surveys for blue whales at South Georgia. The vocalisations of blue whales, in particular Antarctic blue whales, are low frequency and very loud and can be detected acoustically from considerable distances, greatly in excess of visual detection ranges (McDonald et al. 2006, Širović et al. 2006, 2007, Miller et al. 2015). Combined visual and acoustic surveys may be more efficient at detecting the presence of a low-density but acoustically active population than purely visual methods (Barlow \& Taylor 2005, Peel et al. 2014, Miller et al. 2015, 2016).

Here, we examined data from passive acoustics, dedicated visual surveys for whales and opportunis- 
tic sightings around South Georgia to assess whether there are any trends in blue whale distribution around South Georgia since the end of whaling. We also examined blue whale population identity around South Georgia, considering evidence of movement patterns provided by photo-identification and Discovery mark-recaptures (see Section 2.4) and evaluated whether blue whales may be recovering around South Georgia.

\section{MATERIALS AND METHODS}

To investigate trends in blue whale numbers around South Georgia over the last approximately $30 \mathrm{yr}$ (the period for which data are available), we examined several sources. We defined the area of interest on the basis of whaling records from the 1923/ 1924 to 1930/1931 seasons (Kemp \& Bennett 1932). These data were compiled from forms issued by the Government of the Falkland Islands Dependencies to the whaling companies asking them to give the ap- proximate position of each whale that was killed, and thus provide a useful indication of whale densities and distribution at that time. Kemp \& Bennett (1932, p. 168) stated that

Off the coast of South Georgia the whaling grounds are some 300 miles both in length and breadth, embracing an area of over 50000 square miles.

We evaluated survey effort within an area bounded by $52-57^{\circ} \mathrm{S}, 43.5-32.5^{\circ} \mathrm{W}$, which included the former whaling grounds and the separate area of shallow shelf waters to the west of the island around Shag Rocks, where very few blue whales were caught, either from shore-based whaling or later pelagic whaling from factory ships, including illegal Soviet whaling (Fig. 2) (Branch et al. 2007b).

Data sources reviewed here (Table 1) comprise opportunistic sightings, systematic visual surveys and passive acoustic observations from platforms of opportunity or dedicated whale surveys, photoidentification data and data from Discovery marks (Branch et al. 2007b).

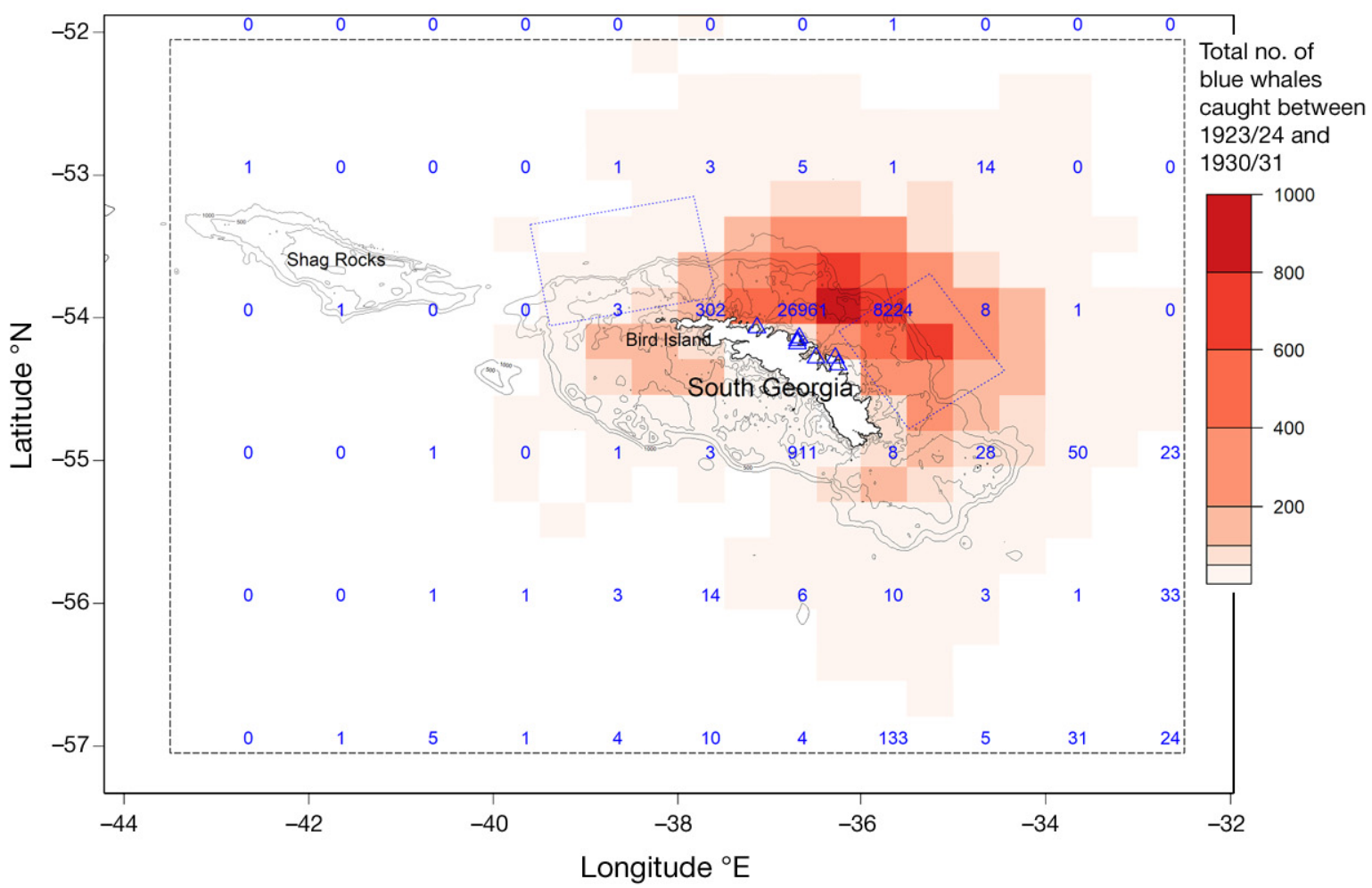

Fig. 2. Blue whale catch data around South Georgia. Red shading: intensity of blue whale catches around South Georgia from 8 seasons (1923/1924 to 1930/1931), representing position of capture for 13261 whales (red shading giving total numbers by grid square $\left[0.25^{\circ}\right.$ latitude by $0.5^{\circ}$ longitude] based on plots from Kemp \& Bennett 1932). Blue numbers: total catches of blue whales from 1913-1970 (shore stations, pelagic and Soviet whaling) by $1^{\circ}$ rectangle. Catches were most often recorded at the location of the shore station rather than the position of capture. Blue triangles mark the 7 shore stations. Location of shorebased catches were mostly recorded as the location of the shore station where they were processed. Black dashed line: area centred on locations of most intense whaling, but also including the Shag Rocks shelf area, for which effort from surveys was compared. Blue boxes: British Antarctic Survey Western and Eastern 'Core Box' survey areas 
Table 1. Data sources reviewed in this study, covering the time period 1991-2020. Abbreviations - BAS: British Antarctic Survey; IWC: International Whaling Commission

\begin{tabular}{|c|c|c|}
\hline Data source & Time period covered & Description \\
\hline South Georgia Museum & $1991-2020$ & $\begin{array}{l}\text { Opportunistic sightings reported to the South Georgia Museum by } \\
\text { mariners and vessel passengers }\end{array}$ \\
\hline Bird Island & $1998-2019$ & Opportunistic land-based sightings by BAS field researchers \\
\hline Visual surveys & $\begin{array}{l}\text { Various years from } \\
1997-2020\end{array}$ & $\begin{array}{l}\text { Quantified-effort surveys by dedicated research vessels } \\
\text { (see Table } 2 \text { for more detailed description) }\end{array}$ \\
\hline Passive acoustic surveys & $2003,2017,2018,2020$ & Quantified-effort surveys from research vessels using sonobuoys \\
\hline $\begin{array}{l}\text { Passive acoustics from } \\
\text { acoustic moorings }\end{array}$ & $2006-2008$ & $\begin{array}{l}\text { Long-term passive acoustic monitoring from a location to NW of } \\
\text { South Georgia }\end{array}$ \\
\hline Photo-identification & $2011-2020$ & $\begin{array}{l}\text { Photographs taken of blue whales identifying them as individuals } \\
\text { (from Antarctic blue whale catalogue [IWC]) }\end{array}$ \\
\hline
\end{tabular}

\subsection{Opportunistic data}

Some of the opportunistic data (sightings made from land [Bird Island] and sightings made by other vessels and kept by the South Georgia Museum) have been previously published in reviews by Moore et al. (1999) and Richardson et al. (2012). Moore et al. (1999) summarised sightings of large whales around South Georgia from their own survey in 1997, sightings made from Bird Island (at the west end of South Georgia; Fig. 2) from 1979-1998 and sightings made by other vessels from 1992-1997 and kept by the South Georgia Museum. Richardson et al. (2012) reviewed South Georgia Museum data and observations from Bird Island from 1991-2010. The methodology of data collection for the Bird Island and South Georgia Museum datasets is described by Moore et al. (1999) and Richardson et al. (2012).

\subsection{Data from systematic visual surveys}

Systematic surveys that collected visual data are listed in Table 2. Some of these data have already been published, either in peer-reviewed literature or cruise reports. Several of the datasets are from British Antarctic Survey (BAS) Western and Eastern Core Box surveys (the positions of which are shown in Fig. 2), Joint Nature Conservation Committee (JNCC) Seabirds at Sea surveys and surveys for the Government of South Georgia and the South Sandwich Islands (GSGSSI) which, whilst not dedicated whale surveys, provided platforms of opportunity for whale observers to undertake visual observations during other survey activities. The blue whale sightings from dedicated surveys can be compared to investigate any changes in blue whale encounters per unit effort over time.

\subsection{Passive acoustic monitoring}

During the 2000s, there were 2 passive acoustic data collection projects around South Georgia. Širović at al. (2006) deployed omnidirectional and directional frequency analysis and recording (DIFAR) sonobuoys (which enable the detection of both whale vocalisations and the bearings to those vocalisations) in January and February 2003 in conjunction with BAS Scotia Sea and Western Core Box visual surveys. Since passive acoustic monitoring during the survey was largely opportunistic, information on the direction of detected calls could not be used to track down whales or confirm their location. A marine acoustic recording unit was deployed on the shelf to the northwest of South Georgia $\left(53.8^{\circ} \mathrm{S}, 37.9^{\circ} \mathrm{W}\right)$ at depths of 200 to $300 \mathrm{~m}$ over 3 deployments between April 2006 and June 2007 (Pangerc 2010). It sampled at $1 \mathrm{kHz}$ on a $50 \%$ duty cycle (30 min on/30 min off).

In recent years, there has been increased passive acoustic data collection effort; passive acoustic data were collected in 2017 (Miller et al. 2017), 2018 (Jackson et al. 2020) and 2020 (Kennedy et al. 2020) using DIFAR sonobuoys. The equipment (sonobuoys, receiving hardware and software) and real-time whale call detection and processing protocols for these surveys largely followed the methodology described by Miller et al. (2015). However, Miller et al. (2015) used passive acoustics specifically to locate blue whales in real time, whilst the 2017, 2018 and 2020 research cruises prioritised other research activities, so the deployment location of sonobuoys was often opportunistic and no real-time acoustic tracking of blue whales took place.

For these passive acoustic monitoring surveys, blue whale detections were examined to determine likely locations of vocalising whales. Blue whale vocalisa- 
Table 2. Systematic, quantified-effort visual surveys conducted around South Georgia, 1997-2020. Abbreviations as follows BAS: British Antarctic Survey; JNCC: Joint Nature Conservation Committee; CCAMLR: Commission for the Conservation of Antarctic Marine Living Resources; GSGSSI: Government of South Georgia and the South Sandwich Islands

\begin{tabular}{|c|c|c|c|c|}
\hline Year & Start date & End date & Name of survey or source & Description of South Georgia survey effort \\
\hline 1997 & $27 \mathrm{Jan}$ & 13 Feb & Moore et al. (1999) & $\begin{array}{l}\text { Transect lines along N coast. Survey start/end in } \\
\text { Shag Rocks area }\end{array}$ \\
\hline 1998 & $17 \mathrm{Jan}$ & 5 Feb & BAS Core Box (Reid et al. 2000) & West (W) and East (E) Core Boxes \\
\hline 1998 & October & November & JNCC Seabirds at Sea & South Georgia waters (primarily 1000 m contour) \\
\hline 1998/99 & $929 \mathrm{Dec}$ & 5 Jan & BAS Core Box (Leaper et al. 1999) & W and E Core Boxes (dual platform) \\
\hline 1999 & \multicolumn{2}{|c|}{ Various months } & JNCC Seabirds at Sea & South Georgia waters (primarily 1000 m contour) \\
\hline 2000 & 7 Jan & 28 Jan & CCAMLR 2000 (Reilly et al. 2004) & Transect lines around island, mostly to north \\
\hline 2000 & \multicolumn{2}{|c|}{ January and May } & JNCC Seabirds at Sea & South Georgia waters (primarily 1000 m contour) \\
\hline 2001 & July & August & JNCC Seabirds at Sea & South Georgia waters (primarily 1000 m contour) \\
\hline $2002 \mathrm{O}$ & \multirow{2}{*}{\multicolumn{2}{|c|}{$\begin{array}{l}\text { October and December } \\
\text { January to December }\end{array}$}} & GSGSSI & South Georgia waters (primarily 1000 m contour) \\
\hline 2003 & & & GSGSSI & $\begin{array}{l}\text { W Core Box plus track from Shag Rocks plus other } \\
\text { South Georgia waters (primarily } 1000 \text { m contour) }\end{array}$ \\
\hline 2003 & 29 Jan & $19 \mathrm{Feb}$ & BAS Core Box (Širović et al. 2006) & W Core Box plus Scotia Sea \\
\hline $2004 \mathrm{~J}$ & \multicolumn{2}{|c|}{ January to September } & GSGSSI & $\begin{array}{l}\text { W Core Box plus other South Georgia waters } \\
\text { (primarily } 1000 \text { m contour) }\end{array}$ \\
\hline 2006 & $28 \mathrm{Jan}$ & 2 March & Rossi-Santos et al. (2007) & Surveys off $N$ coast \\
\hline 2006 & 24 Oct & $3 \mathrm{Dec}$ & $\begin{array}{l}\text { BAS Discovery } 2010 \text { Spring } \\
\text { (Tarling et al. 2012) }\end{array}$ & Track to NW, W and SW of island \\
\hline $2007 / 8$ & $31 \mathrm{Dec}$ & $16 \mathrm{Feb}$ & $\begin{array}{l}\text { BAS Discovery } 2010 \text { Summer } \\
\text { (Tarling et al. 2012) }\end{array}$ & $\begin{array}{l}\text { Track to W and SW of island, N coast and } \\
\text { passage towards Falklands }\end{array}$ \\
\hline 2009 & $11 \mathrm{March}$ & 18 April & $\begin{array}{l}\text { BAS Discovery } 2010 \text { Autumn } \\
\text { (Tarling et al. 2012) }\end{array}$ & $\begin{array}{l}\text { Track to N, NW, W and SW of island. Small-scale } \\
\text { surveys each } 150 \mathrm{~km} \text { long }\end{array}$ \\
\hline 2017 & $23 \mathrm{Jan}$ & $28 \mathrm{Jan}$ & $\begin{array}{l}\text { Dolphins of the Kelp/HMS } \\
\text { 'Enterprise' (Garcia \& Costa 2017) }\end{array}$ & $\begin{array}{l}\text { Track along N coast to SE of island and passage } \\
\text { to/from island from Falklands }\end{array}$ \\
\hline 2018 & $28 \mathrm{Jan}$ & $16 \mathrm{Feb}$ & $\begin{array}{l}\text { BAS Southern Right Whale } \\
\text { cruise (Jackson et al. 2020) }\end{array}$ & $\begin{array}{l}\text { Transects off } \mathrm{N} \text { coast; passage to/from SG } \\
\text { from west }\end{array}$ \\
\hline 2019 & 5 Jan & 10 Feb & $\begin{array}{l}\text { RRS ‘Discovery' DY098 } \\
\text { (Baines et al. 2019) }\end{array}$ & Transects off $N$ coast \\
\hline 2020 & 9 Jan & $3 \mathrm{Feb}$ & $\begin{array}{l}\text { BAS Southern Right Whale } \\
\text { cruise (Kennedy et al. 2020) }\end{array}$ & $\begin{array}{l}\text { Transects around whole island and passage to/ } \\
\text { from island from west, including Shag Rocks }\end{array}$ \\
\hline
\end{tabular}

tions comprise both stereotyped, regularly repeated song (thought to be produced only by males) and frequency-modulated calls (' $\mathrm{D}$ ' or 'FM' calls), which are thought to be produced by both sexes and are associated with group and foraging behaviours (McDonald et al. 2001, Oleson et al. 2007). Although song from Antarctic blue whales was recorded during surveys, only D-calls were used in this study to estimate whale locations, as they are not detected over such great distances as song, and have been demonstrated to be a good indicator of proximity to blue whale groups (Miller et al. 2015).

If simultaneous bearings can be obtained from more than 1 sonobuoy, then it is usually possible to derive a whale location. For many of the more recent data considered here, vocalising aggregations of whales at similar locations were detected on multiple sonobuoys, but not simultaneously. An approximate estimate of location along a bearing line can also be obtained if the received sound pressure level of the call can be measured, and if the source level and propagation loss can be estimated. For the purposes of this study, we used a combination of simple assumptions about acoustic parameters to estimate a possible location for each call received, to obtain a broad-scale picture of blue whale distribution from the acoustic data. We assumed a simple spherical spreading propagation loss of $20 \log _{10}(r)$ in $\mathrm{dB}$ at a distance of $r$ metres from the source. Sound pressure levels (re $1 \mu \mathrm{Pa}^{2}$ ) were obtained from the recording system following the 'intensity calibration' methods presented by Rankin et al. (2019). These were converted to sound pressure spectral density levels (dB re $1 \mu \mathrm{Pa}^{2} / \mathrm{Hz}$ ) by subtracting $10 \log (B)$, where $B$ is the bandwidth of the call (in $\mathrm{Hz}$ ). 
The simple visual plots presented aim to provide a visual indication of concentrations of vocalising whales. We represent the uncertainty around each whale location with respect to source level with an ellipse, the main axis of which is along the bearing line, and the endpoints of which are estimated based on a sound pressure spectral density level at a distance of $1 \mathrm{~m}$ of between 160 and $170 \mathrm{~dB}$ re $1 \mu \mathrm{Pa}^{2} / \mathrm{Hz}$. These estimates are derived from measurements of a small number of blue whale D-calls from the North Pacific (Thode et al. 2000) and Northeast Atlantic (Akamatsu et al. 2014). To simplify the plots and avoid very large apparent detection distances, we truncated the $10 \%$ of calls with the lowest received levels in each annual data set.

Propagation losses around South Georgia are unlikely to consistently follow a spherical spreading law given the complex bathymetry and shallow soundspeed minimum in the survey region. Estimates of location based on received levels associated with each bearing will therefore have considerable uncertainty. However, the overall distribution of acoustic locations illustrates the likely distribution of calling whales.

\subsection{Photo-identification and Discovery marks}

Photo-identifications of individual blue whales at South Georgia were obtained from research cruises conducted in 2018-2020 (Table 2) and from naturalists on tourist vessels (2011-2020). Blue whales are identified as individuals based on mottling pigmentation and the shape of the dorsal fin. The identification photographs collected at South Georgia were compared to one another and to photographs from the circumpolar Antarctic from 1980-2019 ( $\mathrm{n}=517$; Olson et al. 2020a). Methods of comparison followed those outlined by Sears et al. (1990). Mark-recapture data from blue whales marked during the Discovery investigations (between 1934 and 1962), which used marked metal tubes fired into whales that were sometimes recovered by whaling operations (Branch et al. 2007b), were also reviewed to assess blue whale site fidelity.

\section{RESULTS}

\subsection{Opportunistic data}

The South Georgia Museum sightings from mariners and passengers recorded 42 sightings of blue whales (comprising over 100 individuals) from 1991 to 2020. The location of these sightings largely reflects the routes taken by cruise ships, since cruise ship sightings comprise the majority of Museum sightings. One-third of sightings are from around the Shag Rocks area, and the remainder are quite scattered, but with the majority along well-travelled routes off the north coast of South Georgia (Fig. 3). The number of sightings reported varied between 0 and 4 groups per year, with no obvious trend over time. Cruise ship traffic increased over this period ${ }^{\mathbf{1}}$, but there was no significant trend in the number of sightings per cruise ship visit. No blue whales were seen from Bird Island between 1998 and 2019.

\subsection{Data from systematic visual surveys}

Over $39000 \mathrm{~km}$ of visual survey effort were conducted between 1997 and 2020. Much of this effort

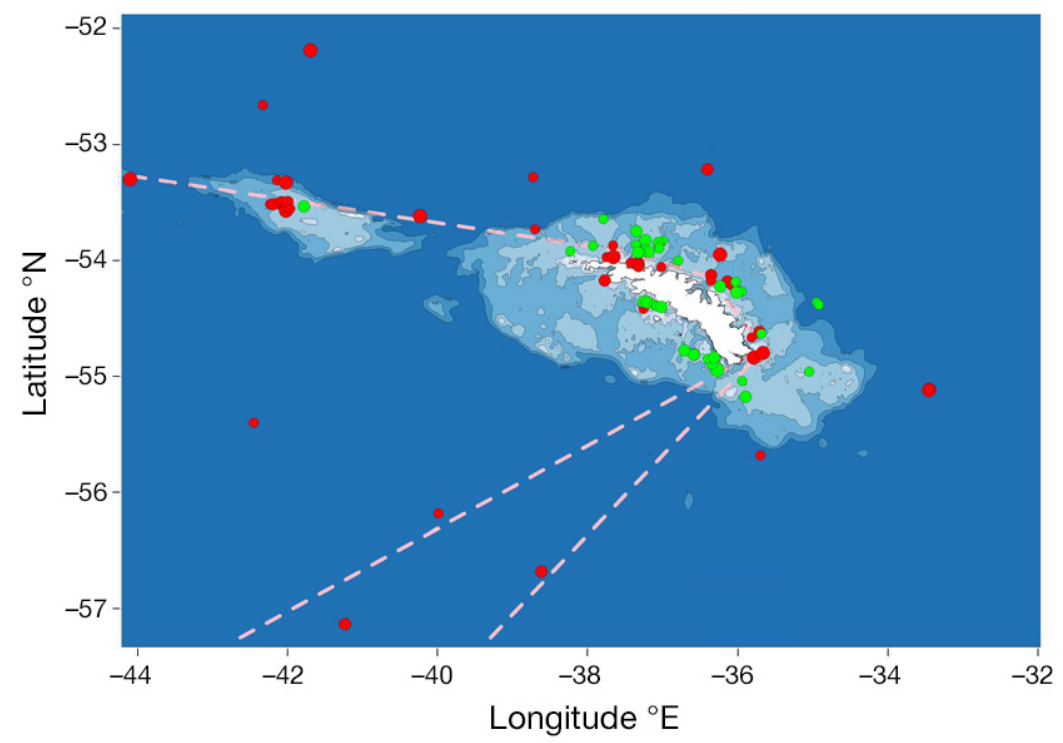

Fig. 3. All blue whale visual records from both opportunistic sighting records and systematic surveys since 1991. Red dots indicate all sightings except those from 2020 survey, which are green. Size of dot indicates group size 1, 2, > 2 . Pink dashed lines indicate main routes taken by cruise ships

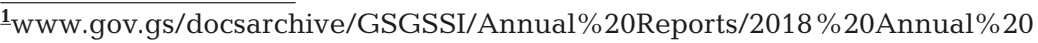
Report\%20Government\%20of\%20South\%20Georgia\%20\&\%20the\%20South $\% 20$ Sandwich $\% 20$ Island.pdf
} 
was on the north side of the island, and also included transits to and from the island from the west via Shag Rocks. During these surveys, 47 blue whale sightings were recorded, comprising 73 animals (Table 3 ). On most of the surveys there were no blue whale sightings. Moore et al. (1999) noted a blue whale sighting (of a mother-calf pair off the Shag Rocks, February 1997); the Commission for the Conservation of Antarctic Marine Living Resources - International Whaling Commission (CCAMLR-IWC) Krill Synoptic Survey across the Scotia Sea and around the Antarctic Peninsula using 3 ships with cetacean observers did not record any blue whale sightings within the South Georgia/Shag Rocks area (Reilly et al. 2004, Watkins et al. 2004). On BAS surveys of Western and Eastern Core Box areas (Reid et al. 2000), JNCC Seabirds at Sea surveys and GSGSSI surveys between 1998 and 2004 (the latter primarily along the $1000 \mathrm{~m}$ contour), 1 blue whale was sighted in May 2003 (on a GSGSSI survey). On the Discovery 2010 science programme cruises (2006-2009) where cetacean observers were onboard, no blue whales were sighted. Rossi-Santos et al. (2007) carried out 13 whale survey trips over the period from 28 January to 2 March 2006, covering $1300 \mathrm{~km}$ and $110 \mathrm{~h}$ of observation and saw no blue whales.

However, in 2018 a BAS survey focussing on southern right whales sighted a group of 3 blue whales
(Jackson et al. 2020); the RRS 'Discovery' (DY098) cruise of 2019 recorded 6 sightings of 9 individual blue whales (Baines et al. 2019); a BAS survey in 2020 focussing on southern right whales, which included effort from around the whole island, recorded 38 sightings of 58 blue whales of which 23 individual whales were photo-identified and 9 were biopsied (Kennedy et al. 2020).

In summary, the sighting of a single pair of blue whales in 1997 (Moore et al. 1999) was followed by over $34000 \mathrm{~km}$ of systematic survey data between 1998 and 2018 during which there was just 1 sighting of a single blue whale. The sighting rate from the RRS 'Discovery' (DY098) cruise in 2019 (7 individuals per $1000 \mathrm{~km}$, Baines et al. 2019) was substantially higher than this. The sighting rate from the BAS survey in 2020 (24 individuals per $1000 \mathrm{~km}$ ) was higher again than the 2019 survey. These rates can be compared to the 1991/1992 to 2003/2004 IDCR/SOWER circumpolar CPIII surveys (Branch 2007). The SOWER surveys had large teams of observers and high observation positions, resulting in an estimated strip half width of $3.1 \mathrm{~km}$. Most surveys around South Georgia had small observation teams and lower observer platforms than the SOWER surveys. Much of the survey effort was also conducted using JNCC Seabirds at Sea methodology (Camphuysen et al. 2004), with observers only searching on 1 side of the vessel. The

Table 3. Effort and blue whale (BW) sightings from systematic surveys, 1997-2020. Abbreviations as in Table 2

\begin{tabular}{|c|c|c|c|c|}
\hline Year & Name of survey or source & Effort (km) & BW sightings (n) & Individuals (n) \\
\hline 1997 & Moore et al. (1999) & 1300 & 1 & 2 \\
\hline 1998 & BAS Core Box (Reid et al. 2000) & 1600 & 0 & 0 \\
\hline 1998 & JNCC Seabirds at Sea & 544 & 0 & 0 \\
\hline $1998 / 9$ & BAS Core Box & 891 & 0 & 0 \\
\hline 1999 & JNCC Seabirds at Sea & 2711 & 0 & 0 \\
\hline 2000 & CCAMLR 2000 (Reilly et al. 2004) & 2190 & 0 & 0 \\
\hline 2000 & JNCC Seabirds at Sea & 1483 & 0 & 0 \\
\hline 2001 & JNCC Seabirds at Sea & 294 & 0 & 0 \\
\hline 2002 & GSGSSI & 2754 & 0 & 0 \\
\hline 2003 & BAS Core Box (Širović et al. 2006) & 852 & 0 & 0 \\
\hline 2003 & GSGSSI & 8687 & 1 & 1 \\
\hline 2004 & GSGSSI & 7557 & 0 & 0 \\
\hline 2006 & Rossi-Santos et al. (2007) & 1300 & 0 & 0 \\
\hline 2006 & BAS Discovery 2010 Spring (Tarling et al. 2012) & 550 & 0 & 0 \\
\hline $2007 / 8$ & BAS Discovery 2010 Summer (Tarling et al. 2012) & 1100 & 0 & 0 \\
\hline 2009 & BAS Discovery 2010 Autumn (Tarling et al. 2012) & 700 & 0 & 0 \\
\hline 2017 & Dolphins of the Kelp/HMS 'Enterprise' (Garcia \& Costa 2017) & 198 & 0 & 0 \\
\hline 2018 & BAS Southern Right Whale (Jackson et al. 2020) & 606 & $1^{\mathrm{a}}$ & $3^{\mathrm{a}}$ \\
\hline 2019 & RRS 'Discovery' DY098 (Baines et al. 2019) & 1270 & 6 & 9 \\
\hline 2020 & BAS Southern Right Whale (Kennedy et al. 2020) & 2430 & 38 & 58 \\
\hline TOTAL & & 39017 & 47 & 73 \\
\hline
\end{tabular}


lack of sightings precludes estimates of strip width except for 2020, where the estimate was $1.4 \mathrm{~km}$ (Kennedy et al. 2020). If this strip width is assumed to be typical for all the South Georgia surveys, this suggests that the expected sighting rate for an equivalent density of whales would be only $44 \%$ of the SOWER rate. The combined surveys around South Georgia between 1997 and 2018 had sighting rates that were an order of magnitude lower than both the global CPIII SOWER survey and the Area II component (covering longitude $0-60^{\circ} \mathrm{W}$ ) (Table 4 ). In contrast, the 2019 and 2020 surveys had considerably higher sighting rates than either the SOWER CPIII Area II survey or the SOWER CPIII global average. In the case of the 2020 survey, the sighting rate, taking into account the differences in strip widths, is nearly 40 times greater than that of SOWER CPIII Area II.

\subsection{Passive acoustic monitoring}

During sonobuoy deployments in 2003, Antarctic blue whales were detected mostly in the Scotia Sea, south of the southern boundary of the Antarctic Circumpolar Current, with only 2 detections of Antarctic blue whale song (and no D-calls) closer to South Georgia, even though 34 sonobuoys (46 $\mathrm{h}$ of recordings) were deployed in that area. The concurrent visual survey also recorded no blue whale sightings (Širović at al. 2006). Long-term monitoring between 2006 and 2008 detected Antarctic blue whales yearround, with song detections peaking during austral spring, summer and autumn, when there were multiple vocalising animals and song length was longer than in winter. D-calls were also detected, suggesting that by
2006, Antarctic blue whales were present sufficiently close to South Georgia for these D-calls to be detected, although D-call presence was generally lower and absent between December and February (Pangerc 2010). Over the course of 3 surveys in 2017, 2018 and 2020, 72 DIFAR sonobuoys were deployed, representing $211 \mathrm{~h}$ of monitoring (Table 5, Fig. 4).

Although the estimated locations of vocalising blue whales (Fig. 5) are likely associated with consider-

Table 5. Sonobuoy deployments around South Georgia 2003, 2017, 2018, 2020

\begin{tabular}{|ccc|}
\hline Year & $\begin{array}{c}\text { No. of sonobuoy } \\
\text { listening stations }\end{array}$ & Hours of monitoring \\
\hline 2003 & 34 & 46 \\
2017 & 15 & 14 \\
2018 & 26 & 83 \\
2020 & 31 & 114 \\
\hline
\end{tabular}

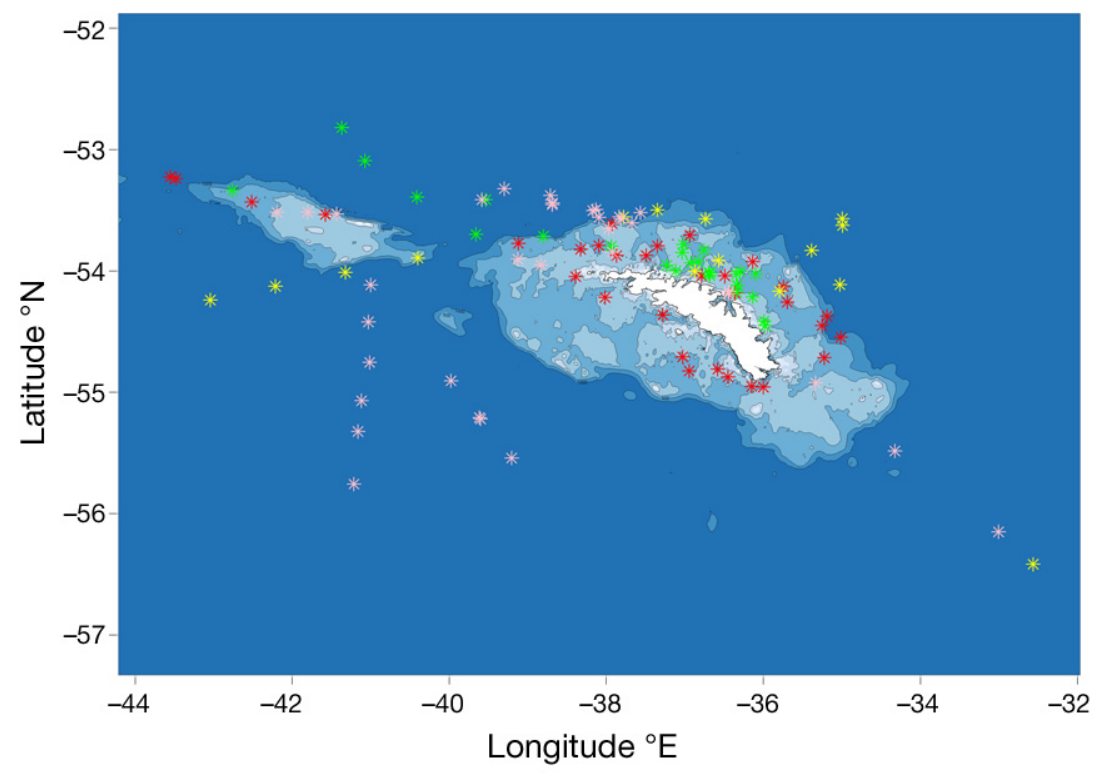

Fig. 4. Locations of sonobuoy deployments. Pink $=2003$; yellow $=2017$; green $=$ 2018; red $=2020$

Table 4. Comparison of blue whale sighting rates. Abbreviations as follows - SOWER: Southern Ocean Whale and Ecosystem Research Programme; CP: circumpolar; BAS: British Antarctic Survey

\begin{tabular}{|lccrc|}
\hline Survey & Period & Effort (km) & No. of schools & $\begin{array}{c}\text { Sighting rate } \\
\text { (schools per 1000 km) }\end{array}$ \\
\hline SOWER global CPII & $1991 / 1992-2003 / 2004$ & 85092 & 68 & 0.80 \\
SOWER CPIII Area II & $1996 / 1997-1997 / 1998$ & 11858 & 11 & 0.93 \\
All South Georgia & $1997-2018$ & 35317 & 2 & 0.06 \\
RRS 'Discovery' DY098 & 2019 & 1270 & 6 & 4.72 \\
BAS 2020 & 2020 & 2430 & 38 & 15.64 \\
\hline
\end{tabular}




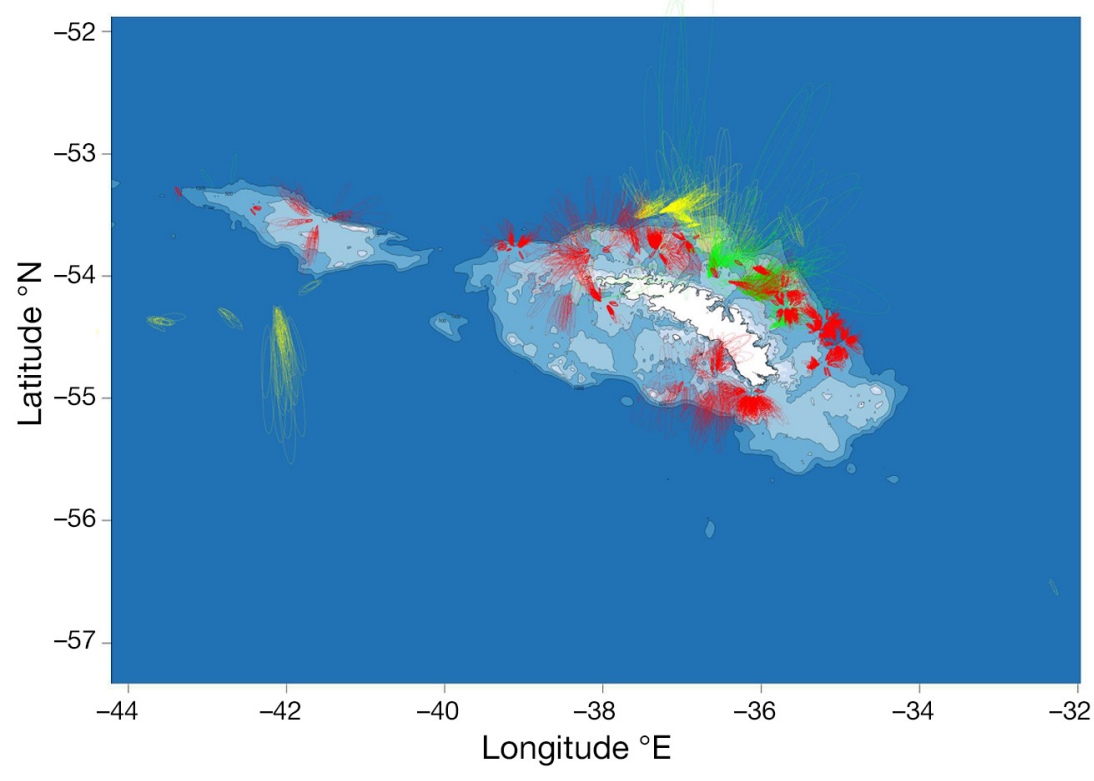

Fig. 5. Estimated locations of D-call vocalisations produced by blue whales: yellow $=2017$; green $=2018$; red $=2020$. Ellipses are drawn with their long axis along bearing lines from DIFAR sonobuoy detections where the end points of the ellipse represent a $10 \mathrm{~dB}$ difference in assumed source level matched to any identification photos from the rest of the Antarctic ( $\mathrm{n}=$ 517; 389 left sides, 383 right sides).

Eleven of the Discovery marks fired into blue whales around South Georgia (within our box $52-57^{\circ} \mathrm{S}$, $\left.32.5-43.5^{\circ} \mathrm{W}\right)$ were subsequently recovered (Branch et al. 2007b). Of these, 7 were recovered within the same season with a median distance of $57 \mathrm{~km}$ between the locations of the whale at deployment and at recovery of the mark. Of the 4 marks that were recovered in different seasons, the median distance between the locations of the whale at deployment and at recovery of the mark was $750 \mathrm{~km}$. One animal was killed close to where it had been marked at South Georgia 12 yr before. In addition, 2 whales marked at $55.8^{\circ} \mathrm{S}$, $000.2^{\circ} \mathrm{W}$ and $56.5^{\circ} \mathrm{S}, 7.0^{\circ} \mathrm{W}$, respectively, were subsequently killed at

South Georgia. Both had travelled

able error, they indicate areas with concentrations of vocalising whales. Qualitatively, the estimated range along each bearing line was consistent with the locations of the triangulations obtained during the 2018 and 2020 surveys. In 2017, all blue whales were detected in deep water, both to the southwest of the island and to the north of the island. In 2018, blue whales were detected on the continental shelf off the northern coast in 3 clusters. In 2020 (the only year with acoustic effort off the south coast of the island), there were multiple whale concentrations on the shelf to the north of South Georgia, and concentrations around the southeast of the island and at the western end, as well as at Shag Rocks.

\subsection{Photo-identification and Discovery marks}

Between 2011 and 2020, 41 individual blue whales (34 left sides, 29 right sides) were photographed at South Georgia (Table 6). Two whales, photographed together on 24 January 2020, were also photographed together again on 29 January 2020. There were no photographic inter-annual matches of whales at South Georgia, and none
Table 6. Dates, sources and locations of photo-identified blue whales at South Georgia, 2011-2019. Abbreviation - BAS: British Antarctic Survey

\begin{tabular}{|c|c|c|c|c|}
\hline Year & Date & Source & No. of IDs & Location \\
\hline 2011 & 18 Nov & Tourist vessel & 1 & East of Clerke Rocks \\
\hline 2015 & 6 Feb & Tourist vessel & 4 & Near Cooper Island \\
\hline 2015 & $28 \mathrm{Feb}$ & Tourist vessel & 4 & South Georgia \\
\hline 2018 & 6 Feb & $\begin{array}{l}\text { BAS Southern } \\
\text { Right Whale }\end{array}$ & 2 & South Georgia \\
\hline 2019 & 24 Jan & $\begin{array}{c}\text { RRS ‘Discovery' } \\
\text { DY098 }\end{array}$ & 1 & South Georgia \\
\hline 2019 & 26 Feb & Tourist vessel & 2 & South Georgia \\
\hline 2020 & $\begin{array}{l}9 \text { Jan- } \\
2 \text { Feb }\end{array}$ & $\begin{array}{l}\text { BAS Southern } \\
\text { Right Whale }\end{array}$ & 23 & South Georgia \\
\hline 2020 & 4 March & Tourist vessel & 4 & South Georgia \\
\hline
\end{tabular}


ploitation of wildlife. Following near-extirpation of fur seals and severe reduction of elephant seals in the $19^{\text {th }}$ century, the first $50 \mathrm{yr}$ of the $20^{\text {th }}$ century transformed South Georgia from a marine habitat with one of the world's highest densities of large whales to an area where all whale species were scarce, and some all but absent.

Whilst seal populations began to recover, it was widely thought that blue whales might never be seen again in significant numbers at South Georgia. Until recent years, scientific surveys and opportunistic cruise ship observations predominantly within the nearshore areas of South Georgia resulted in very few blue whale sightings in areas where they were once abundant. There was a period of 20 yr of systematic surveys with only 1 blue whale sighting from over $34000 \mathrm{~km}$ of effort. However, in recent years, there has at last been some evidence of their return to these historic foraging grounds. The 2020 survey had substantially higher sighting rates than any previous year since the end of commercial whaling.

The strongest evidence for a substantial increase in blue whales around South Georgia within the last few years comes from systematic visual survey data. The passive acoustic data also show substantial differences between 2003, when no D-calls were detected from sonobuoys, and 2017, 2018 and 2020, when these calls were detected at the majority of listening stations on each survey. However, it is not clear how recently blue whales began returning to South Georgia waters; survey effort at South Georgia has never been high, and the apparent lack of recovery may be a symptom of low survey effort, and a resulting low statistical power to detect changes in population density (Clapham et al. 2008). Acoustic technology, which has been demonstrated to detect sparsely distributed blue whales with greater efficiency than visual surveys and can also provide longterm monitoring datasets, has not been available until recent years. However, Pangerc's (2010) longterm acoustic mooring deployments detected Antarctic blue whales around South Georgia in 2006/2007, when blue whales were not yet being observed by visual surveys. In 2017, passive acoustic monitoring indicated blue whales in offshore areas, but not in inshore areas. The 2018 and 2020 passive acoustic data showed whales inshore, with more acoustic groups present in 2020. It is possible that, even during the years when no blue whales were seen around South Georgia in inshore waters, there were whales beyond the shelf break, including offshore areas south of the island that were even more sparsely surveyed (Širović et al. 2006). These data demonstrate the role of passive acoustic monitoring in inferring more broad-scale, long-term patterns in distribution than are possible with visual sightings, and highlight the importance of combined acoustic and visual surveys in examining trends in blue whale distribution.

Although survey effort has been limited, the surveys conducted up until 2018 showed average sighting rates of blue whales that were substantially lower than the average across all Antarctic waters. This indicates that blue whale recovery at South Georgia, which had been one of the highest-density areas for blue whales, accounting for $12 \%$ of the total Southern Hemisphere catch, has been much slower than for the Antarctic as a whole. However, recent surveys in 2019 and 2020 have shown higher numbers of blue whales (and also humpback whales). Future surveys will determine whether these densities seen in 2020 persist in subsequent seasons.

South Georgia still appears to provide important feeding habitat, and blue whales are beginning to return. That this spatial recovery has taken several decades since the end of whaling to begin is indicative of the level of depletion both of the local blue whale population at South Georgia and that of surrounding areas, leaving neither a local remnant population which could recover nor sufficient animals in the adjacent areas for swift recolonisation. The importance of cultural knowledge and fidelity to habitats and maternally-directed learning has been demonstrated in many taxa, and also other species of baleen whale (Carroll et al. 2011, Baker et al. 2013, Carroll et al. 2015), and it is possible that for blue whales too, cultural knowledge directs them to optimal habitats, and that extirpations erase that knowledge (Clapham et al. 2008). Rediscovery of these habitats, if it happens, is generally slow (Carroll et al. 2015). A comparison of mitochondrial DNA haplotype diversity from bones of blue whales taken at South Georgia (Sremba et al. 2015) with contemporary circumpolar samples from IDCR-SOWER demonstrates a post-whaling loss of mtDNA haplotype diversity in Antarctic blue whales, and highlights the great importance of this feeding area for blue whales prior to exploitation (Sremba et al. 2020).

There is some evidence of the use of certain call types during foraging in baleen whales to advertise the presence of prey and foraging to conspecifics, either intentionally or unintentionally (Parks et al. 2014). It has been suggested that blue whale D-calls are related to feeding and/or social behaviour (Oleson et al. 2007), and it is possible that, as blue whale numbers at South Georgia have begun to increase, their calls have advertised the quality of the feeding 
ground to conspecifics further afield, encouraging more animals towards the area.

In addition to the increased use of passive acoustic technology, there has also been a steady rise in the number of cruise ship passengers visiting South Georgia over the last 20 yr from around 2000 in 1998-1999 to over 10000 in the 2017-2018 season? This passenger increase has the potential to increase the number of whale sightings reported to the South Georgia Museum. Over the past $20 \mathrm{yr}$, digital camera technology has also developed rapidly, so the proportion of passengers, naturalists and scientists visiting and working at South Georgia who are able to take high-quality photographs for species and individual identification has also increased. However, although there has been a steady rise in cruise ship numbers to South Georgia, this has not been reflected in the number of blue whale sightings, which would have been expected with a rise in opportunistic effort. Even the high number of blue whales observed during the BAS 2020 survey was not reflected in the opportunistic data which were reported to the $\mathrm{Mu}$ seum over the same time period. There are a number of possible explanations for this, as opportunistic and community sightings data are subject to a number of difficult-to-quantify biases. In the case of South Georgia, a rise in cruise ship passengers does not necessarily mean a rise in whale observers. Furthermore, if whales are perceived as being more common around South Georgia then cruise ship passengers might not be as motivated to report them to the $\mathrm{Mu}$ seum. No blue whales were seen from Bird Island; usually blue whales occur further from the coast and it might be expected that they would not be seen from land, although in 2020 a sighting was reported by BAS scientists very close to land off the north coast of South Georgia (at Maiviken, Cumberland West Bay).

It is interesting that one-third of the opportunistic South Georgia Museum sightings of blue whales are from around the Shag Rocks area to the west of South Georgia, which comprise rocks, shallow water and a shelf break surrounded by deeper water. During whaling, blue whales were not caught in this area, either from shore-based operations or from pelagic factory ships (including illegal Soviet whaling). Although the Shag Rocks area does appear to be important for whales now (Moore et al. 1999), the high pro-

\footnotetext{
$\underline{2}$ www.gov.gs/docsarchive/GSGSSI/Annual\%20Reports/ $2018 \% 20$ Annual \% 20Report\%20Government\% 20 of $\% 20$ South $\% 20$ Georgia $\% 20 \& \% 20$ the $\% 20$ South $\% 20$ Sandwich\%20Island.pdf
}

portion of the Museum sightings which now come from that area is probably an artefact of the majority of cruise ships passing Shag Rocks en route to South Georgia, resulting in high effort.

It is possible that a small proportion of the blue whales caught at South Georgia were pygmy blue whales or Southeast Pacific blue whales, rather than Antarctic blue whales. Some sexually mature female blue whales caught were shorter than expected for Antarctic blue whales and could have been pygmy blue whales (Branch et al. 2007a) or Southeast Pacific blue whales (Branch 2020). However, early length measurements were non-standardised and many were rounded to the nearest $5 \mathrm{ft}(\sim 1.5 \mathrm{~m})$ interval, making it difficult to rely on these data for evidence of the presence of non-Antarctic blue whale subpopulations (Branch et al. 2007a, Branch 2020). Genetic analysis of blue whale bones from South Georgia from the whaling era found 1 haplotype thus far only recorded in the Southeast Pacific (LeDuc et al. 2007, Sremba et al. 2015, 2018), and 1 individual biopsied in Antarctic waters south of South Georgia was assigned more closely to Southeast Pacific blue whales (LeDuc et al. 2007, Sremba et al. 2015, 2018).

Contemporaneous evidence of possible Southeast Pacific or pygmy blue whale presence in South Georgia waters comes from acoustics and photo identification. Of the 41 blue whales from South Georgia photographically identified between 2011 and 2020, 4 (all photographed on 28 February 2015) have nonAntarctic morphological characteristics (e.g. prevalent skin lesions and a proportionally shorter tail stock) that suggest non-Antarctic origins (see Olson et al. 2015). However, a comparison of blue whale photographs from South Georgia, 2011-2019 ( $\mathrm{n}=14$; including the 4 whales from 28 February 2015) to photographic catalogues from Chile (total $n=478)^{\frac{3}{3}}$, did not yield any matches (Olson et al. 2020b). Pangerc (2010) recorded faint and incomplete Southeast Pacific-type blue whale vocalisations in August 2006, although these calls were greatly outnumbered in quantity and intensity by calls from Antarctic blue whales, suggesting a rare winter-time vagrant (Pangerc 2010, Širović et al. 2018). Acoustic data collected from DIFAR sonobuoys during the summer months in 2017, 2018 and 2020 only detected Antarctic-type blue whale song calls. In totality, the whaling and more recent data appear to suggest that if any non-Antarctic blue whales are present in South Georgia waters, they are greatly outnumbered by Antarctic blue whales.

\footnotetext{
$\underline{3}$ Centro de Conservación Cetacea; Fundación MERI; International Whaling Commission
} 
It has been suggested that Antarctic blue whales using South Georgia waters are part of the broader metapopulation in the Southern Ocean (Sremba et al. 2012, Attard et al. 2016). Given that the inter-year resighting rate within the Antarctic catalogue is $3.1 \%$ (Olson et al. 2020a), the expected number of resightings is 1.3 if all 41 photo-identified South Georgia blue whales are Antarctic blue whales. From a Poisson distribution, there is a $28 \%$ probability of observing 0 resights when the expected value is 1.3. Therefore, it is not possible based on the results here to make any inference about whether or not blue whales at South Georgia are part of a panmictic Antarctic population. The data from Discovery marks examined by Branch et al. (2007b) show a level of site fidelity, but also show that some blue whales at South Georgia had made substantial longitudinal movements. The variation in movement patterns is similar to that of blue whales throughout the Southern Ocean (Branch et al. 2007b, Olson et al. 2020a).

The apparent increase in density of large whales at South Georgia, both blue whales and other species such as fin whales and humpback whales (Baines et al. 2019, Kennedy et al. 2020) may have implications for management of activities that may affect whales. Shipping traffic in South Georgia is steadily increasing, with a rise in seasonal tourism. Potential impacts from shipping are primarily underwater noise and the risk of ship strikes, which have been addressed in other areas through rerouting of shipping or speed restrictions (IWC 2016, McKenna et al. 2017). Whilst there is a seasonal krill fishery at South Georgia, there is a designated marine protected area in place, with measures including fisheries no-take zones and temporal and spatial protection measures, such as a fishing ban within 12 nautical miles of the South Georgia coast, and closure of the krill fishery during the summer ${ }^{4}$ (Trathan et al. 2014). Assessments of the potential impact of the krill fishery on blue whales around South Georgia will require estimates of abundance, whereas data on distribution patterns are important from the perspective of managing risks from shipping and other fisheries interactions. It is likely that a carefully designed combination of visual and passive acoustic surveys will be the most effective way of monitoring both abundance and distribution.

\footnotetext{
$\overline{4}$ www.gov.gs/docsarchive/Environment/Marine $\% 20$ Protected \% 20Area/MPA \% 20Management $\% 20$ Plan $\% 20$ v2.0.pdf
}

Acknowledgements. It is a pleasure to acknowledge the assistance of the following people and organisations: the Government of South Georgia \& the South Sandwich Islands for permission to use their survey data; the 20162017 Antarctic Circumnavigation Expedition (ACE), carried out under the auspices of the Swiss Polar Institute and supported by funding from the ACE Foundation and Ferring Pharmaceuticals, along with major funding for the passive acoustic survey during ACE provided by the Swiss Polar Institute and the Australian Antarctic Division; Bárbara Galletti Vernazzani of Centro de Conservación Cetacea, Chile, and Sonia Español-Jiménez of Fundación MERI, Chile, kindly shared their blue whale catalogues for the comparison of photographs with those from South Georgia; Mick Baines, Lisa Ballance, Santiago Imberti, Mike Greenfelder, Amy Kennedy, Bob Lamb, Stephanie Martin, Maren Reichelt and Conor Ryan contributed photo-ID images from South Georgia; Tim and Pauline Carr initiated the South Georgia Museum sightings record, and since then staff and volunteers at the Museum and South Georgia Heritage Trust have continued to compile these data; EU BEST 2.0 Medium grant 1594, DARWIN PLUS grant 057, South Georgia Heritage Trust and Friends of South Georgia Island funded the 2018 and 2020 BAS surveys which generated acoustic, photo-ID and sightings data; Friends of South Georgia Island and South Georgia Heritage Trust provided funding to enable the analysis of blue whale identification photos by P.A.O., and for the writing and publication of this manuscript. This paper was substantially improved by comments from Eric Archer (NOAA) and 3 anonymous reviewers. The collection of data gathered here represents a huge effort over the years by observers, scientists and boat crews, and we thank you all for your dedication.

\section{LITERATURE CITED}

Akamatsu T, Rasmussen M, Iversen M (2014) Acoustically invisible feeding blue whales in Northern Icelandic waters. J Acoust Soc Am 136:939-944

Atkinson A, Whitehouse MJ, Priddle J, Cripps GC, Ward P, Brandon MA (2001) South Georgia, Antarctica: a productive, cold water, pelagic ecosystem. Mar Ecol Prog Ser 216:279-308

Attard CRM, Beheregaray LB, Möller LM (2016) Towards population-level conservation in the critically endangered Antarctic blue whale: the number and distribution of their populations. Sci Rep 6:22291

*Baines M, Reichelt M, Lacey C, Pinder S and others (2019) Density and abundance estimates of baleen whales recorded during the 2019 DY098 cruise in the Scotia Sea around South Georgia and the South Sandwich Islands. Report to CCAMLR WG-EMM. https://www.ccamlr.org/ en/wg-emm-2019/27 (accessed 28 August 2020)

Baker CS, Steel D, Calambokidis J, Falcone E and others (2013) Strong maternal fidelity and natal philopatry shape genetic structure in North Pacific humpback whales. Mar Ecol Prog Ser 494:291-306

Barlow J, Taylor BL (2005) Estimates of sperm whale abundance in the northeastern temperate Pacific from a combined acoustic and visual survey. Mar Mamm Sci 21: 429-445

Bonner WN (1958) Exploitation and conservation of seals in South Georgia. Oryx 4:373-380 
Bonner WN (1968) The fur seal of South Georgia. British Antarctic Survey Scientific Reports 56. http://nora.nerc. ac.uk/id/eprint/509253/ (accessed 28 August 2020)

Boyd IL, Walker TR, Poncet J (1996) Status of southern elephant seals at South Georgia. Antarct Sci 8:237-244

Branch TA (2007) Abundance of Antarctic blue whales south of $60^{\circ} \mathrm{S}$ from three complete circumpolar sets of surveys. J Cetacean Res Manag 9:253-262

Branch TA (2020) Assignment of South Georgia catches between Southeast Pacific blue whales and Antarctic blue whales. Paper SC/68B/SH16 presented to IWC Scientific Committee, 2020, Virtual Meeting. https:// archive.iwc.int/pages/search.php?search=!collection299 $55 \&$ bc_from $=$ themes

Branch TA, Matsuoka K, Miyashita T (2004) Evidence for increases in Antarctic blue whales based on Bayesian modelling. Mar Mamm Sci 20:726-754

*Banch TA, Abubaker EMN, Mkango S, Butterworth DS (2007a) Separating southern blue whale subspecies based on length frequencies of sexually mature females. Mar Mamm Sci 23:803-833

Branch TA, Stafford KM, Palacios DM, Allison C and others (2007b) Past and present distribution, densities and movements of blue whales in the Southern Hemisphere and northern Indian Ocean. Mammal Rev 37:116-175

Branch TA, Allison C, Mikhalev YA, Tormosov D, Brownell RL (2008) Historical catch series for Antarctic and pygmy blue whales. Paper SC/60/SH9 presented to IWC Scientific Committee, 2008, Santiago, Chile. Available from IWC Secretariat

Branch TA, Lobo AS, Purcell SW (2013) Opportunistic exploitation: an overlooked pathway to extinction. Trends Ecol Evol 28:409-413

Camphuysen CJ, Fox AD, Leopold MF, Petersen IK (2004) Towards standardised seabirds at sea census techniques in connection with environmental impact assessments for offshore wind farms in the U.K.: a comparison of ship and aerial sampling methods for marine birds, and their applicability to offshore wind farm assessments. NIOZ report to COWRIE - BAM-02-2002 Texel. https://tethys. pnnl.gov/sites/default/files/publications/Camphuysenet-al-2004-COWRIE.pdf (accessed 28 August 2020)

* Carroll E, Patenaude N, Alexander A, Steel D and others (2011) Population structure and individual movement of southern right whales around New Zealand and Australia. Mar Ecol Prog Ser 432:257-268

* Carroll EL, Baker CS, Watson M, Alderman R and others (2015) Cultural traditions across a migratory network shape the genetic structure of southern right whales around Australia and New Zealand. Sci Rep 5:16182

* Clapham PJ, Aguilar A, Hatch LT (2008) Determining spatial and temporal scales for management: lessons from whaling. Mar Mamm Sci 24:183-201

Corkeron P, Hamilton P, Bannister J, Best P and others (2018) The recovery of North Atlantic right whales, Eubalaena glacialis, has been constrained by humancaused mortality. R Soc Open Sci 5:180892

Fielding S, Watkins JL, Trathan PN, Enderlein P and others (2014) Interannual variability in Antarctic krill (Euphausia superba) density at South Georgia, Southern Ocean: 1997-2013. ICES J Mar Sci 71:2578-2588

Foley CM, Lynch HJ (2020) A method to estimate preexploitation population size. Conserv Biol 34:256-265

Garcia MI, Costa M (2017) Cetacean observations between the Falkland Islands and South Georgia conducted on board of the HMS Enterprise from the 21st to the 31st of January 2017. Dolphins of the Kelp Project, SAERI. https:// www.south-atlantic-research.org/wp-content/uploads/ 2019/01/South_Georgia_HMS-Enterprise_Report_2017_ light.pdf (accessed 28 August 2020)

Hogg OT, Barnes DKA, Griffiths HJ (2011) Highly diverse, poorly studied and uniquely threatened by climate change: an assessment of marine biodiversity on South Georgia's continental shelf. PLOS ONE 6:e19795

* IWC (2016) Information on recent outcomes regarding minimizing ship strikes to cetaceans. Paper MEPC 69/ 10/3 presented to the IMO Marine Environment Protection Committee. February 2016. Available from IWC Secretariat

Jackson JA, Kennedy A, Moore M, Andriolo A and others (2020) Have whales returned to a historical hotspot of industrial whaling? The pattern of southern right whale (Eubalaena australis) recovery at South Georgia. Endang Species Res 43:323-340

Kemp S, Bennett AG (1932) On the distribution and movements of whales on the South Georgia and South Shetland whaling grounds. Discovery Reports VI. Cambridge University Press. https://www.biodiversitylibrary.org/ item/28417\#page/9/mode/1up (accessed 28 August 2020)

Kennedy AS, Carroll EL, Baker S, Bassoi M and others (2020) Whales return to the epicentre of whaling? Preliminary results from the 2020 cetacean survey at South Georgia (Islas Georgias del Sur). Paper SC/68B/CMP22 presented to IWC Scientific Committee 2020, Virtual Meeting. https://archive.iwc.int/pages/search.php?search $=$ !collection29934\&bc_from=themes

Leaper R, Reid K, Papastavrou V (1999) Calibration of cetacean data from multidisciplinary surveys around South Georgia using a second independent observation platform. Paper SC/M99/SOWER17 presented to IWC SOWER 2000 workshop, Edinburgh, 1999. Available from IWC Secretariat

KLeaper R, Cooke J, Trathan P, Reid K, Rowntree V (2006) Global climate change drives southern right whales (Eubalaena australis) population dynamics. Biol Lett 2:289-292

LeDuc RG, Dizon AE, Goto M, Pastene LA and others (2007) Patterns of genetic variation in Southern Hemisphere blue whales, and the use of assignment test to detect mixing on the feeding grounds. J Cetacean Res Manag 9: 73-80

McDonald MA, Calambokidis J, Teranishi AM, Hildebrand JA (2001) The acoustic calls of blue whales off California with gender data. J Acoust Soc Am 109:1728-1735

McDonald MA, Mesnick SL, Hildebrand JA (2006) Biogeographic characterisation of blue whale song worldwide: using song to identify populations. J Cetacean Res Manag 8:55-65

*McKenna M, Gabriele C, Kipple B (2017) Effects of marine vessel management on the underwater acoustic environment of Glacier Bay National Park, AK. Ocean Coast Manag 139:102-112

Miller BS, Barlow J, Calderan S, Collins K and others (2015) Validating the reliability of passive acoustic localisation: a novel method for encountering rare and remote Antarctic blue whales. Endang Species Res 26:257-269

Miller BS, Calderan S, Gillespie D, Weatherup G, Leaper R, Collins K, Double MC (2016) Software for real-time localization of baleen whale calls using directional sonobuoys: a case study on Antarctic blue whales. J Acoust Soc Am 139:EL83-EL89 
Miller BS, Miller E, Calderan S, Leaper R and others (2017) Circumpolar acoustic mapping of endangered Southern Ocean whales: voyage report and preliminary results for the 2016/17 Antarctic Circumnavigation Expedition. Paper SC/67A/SH/03 presented to IWC Scientific Committee, 2017, Bled, Slovenia. https://archive.iwc.int/pages/ search.php? search=! collection24508\&bc_from=themes

Moore MJ, Berrow SD, Jensen BA, Carr P and others (1999) Relative abundance of large whales around South Georgia (1979-1998). Mar Mamm Sci 15:1287-1302

Murphy EJ, Watkins JL, Meredith MP, Ward P, Trathan PN, Thorpe SE (2004) Southern Antarctic Circumpolar Current Front to the northeast of South Georgia: horizontal advection of krill and its role in the ecosystem. J Geophys Res Oceans 109:C01029

Oleson EM, Wiggins SM, Hildebrand JA (2007) Temporal separation of blue whale call types on a southern California feeding ground. Anim Behav 74:881-894

Olson PA, Ensor P, Olavarria C, Bott N and others (2015) New Zealand blue whales: residency, morphology, and feeding behavior of a little-known population. Pac Sci 69: 477-485

Olson PA, Double M, Matsuoka K, Pastene LA, Findlay K (2020a) The Antarctic Blue Whale Catalogue: new data from 2015-2019. Paper SC/68B/PH04 presented to IWC Scientific Committee, 2020, Virtual Meeting. https:// archive.iwc.int/pages/search.php? search=! collection299 49\&bc_from=themes

Olson PA, Galletti Vernazzani B, Español-Jiménez S (2020b) Using photo-identification to investigate the identity of blue whales at South Georgia: a comparison of photographs with Chile. Paper SC/68B/SH13 presented to IWC Scientific Committee, 2020, Virtual Meeting. https:// archive.iwc.int/pages/search.php? search=!collection299 $55 \&$ bc_from $=$ themes

Pangerc T (2010) Baleen whale acoustic presence around South Georgia. PhD thesis, University of East Anglia, Norwich. https://ueaeprints.uea.ac.uk/id/eprint/19109/ (accessed 28 August 2020)

* Parks SE, Cusano DA, Stimpert AK, Weinrich MT, Friedlaender AS, Wiley DN (2014) Evidence for acoustic communication among bottom foraging humpback whales. Sci Rep 4:7508

Peel D, Miller BS, Kelly N, Dawson S, Slooten E, Double MC (2014) A simulation study of acoustic-assisted tracking of whales for mark-recapture surveys. PLOS ONE 9: e95602

Rankin S, Miller B, Crance J, Sakai T, Keating JL (2019) Sonobuoy acoustic data collection during cetacean surveys. US Department of Commerce, NOAA Tech Memo NMFS-SWFSC614. https://repository.library.noaa.gov/ view/noaa/20265 (accessed 28 August 2020)

Reid K, Brierley AS, Nevitt GA (2000) An initial examination of relationships between the distribution of whales and Antarctic krill (Euphausia superba) at South Georgia. J Cetacean Res Manag 2:143-149

Reilly S, Hedley S, Borberg J, Hewitt R, Thiele D, Watkins J, Naganobu M (2004) Biomass and energy transfer to baleen whales in the South Atlantic sector of the Antarctic. Deep Sea Res II 51:1397-1409

Richardson J, Wood AG, Neil A, Nowacek D, Moore M (2012) Changes in distribution, relative abundance, and species composition of large whales around South Georgia from opportunistic sightings: 1992 to 2011. Endang
Species Res 19:149-156

* Rocha RC Jr, Clapham PJ, Ivashchenko YV (2014) Emptying the oceans: a summary of industrial whaling catches in the 20th century. Mar Fish Rev 76:37-48

* Rossi-Santos MR, Baracho C, Cipolotti S, Marcovaldi E (2007) Cetacean sightings near South Georgia islands, South Atlantic Ocean. Polar Biol 31:63

Sears R, Williamson JM, Wenzel FW, Bérubé M, Gendron D, Jones P (1990) Photographic identification of the blue whale (Balaenoptera musculus) in the Gulf of St. Lawrence, Canada. Rep Int Whaling Comm 12:335-342

Širović A, Hildebrand JA, Thiele D (2006) Baleen whales in the Scotia Sea during January and February 2003. J Cetacean Res Manag 8:161-171

米 Šrović A, Hildebrand JA, Wiggins SM (2007) Blue and fin whale call source levels and propagation range in the Southern Ocean. J Acoust Soc Am 122:1208-1215

พ Širović A, Branch T, Brownell RL Jr, Cerchio S and others (2018) Blue whale song occurrence in the Southern Hemisphere. Paper SC/67B/SH11 presented to IWC Scientific Committee, 2018, Bled, Slovenia. https://archive. iwc.int/pages/search.php? search=! collection29562\&bc_ from=themes

Sremba AL, Hancock-Hanser B, Branch TA, LeDuc RL, Baker CS (2012) Circumpolar diversity and geographic differentiation of mtDNA in the critically endangered Antarctic blue whale (Balaenoptera musculus intermedia). PLOS ONE 7:e32579

* Sremba AL, Martin AR, Baker CS (2015) Species identification and likely catch time period of whale bones from South Georgia. Mar Mamm Sci 31:122-132

* Sremba AL, Lang AR, Saremi N, Shapiro B and others (2018) Loss of maternal lineages in Antarctic blue whales described from whole mitochondrial genomes of historical and contemporary samples. Paper SC/67B/SH02 presented to IWC Scientific Committee, 2018, Bled, Slovenia. https://archive.iwc.int/pages/search.php? search=! collection29562\&bc_from=themes

* Sremba AL, Martin AR, Wilson P, Pitman R, Jackson J, Baker CS (2020) Comparison of mitochondrial DNA haplotype diversity from pre-whaling and post-whaling samples of Antarctic blue whales. Paper SC/68B/SH06 presented to IWC Scientific Committee, 2020, Virtual Meeting. https://archive.iwc.int/pages/search.php?search $=$ !collection29955\&bc_from=themes

*Tarling GA, Ward P, Atkinson A, Collins MA, Murphy EJ (2012) DISCOVERY 2010: spatial and temporal variability in a dynamic polar ecosystem. Deep Sea Res II 59-60: $1-13$

*Thode AM, D'Spain GL, Kuperman WA (2000) Matchedfield processing, geoacoustic inversion, and source signature recovery of blue whale vocalizations. J Acoust Soc Am 107:1286-1300

Trathan PN, Collins MA, Grant SM, Belchier M, Barnes DKA, Brown J, Staniland IJ (2014) The South Georgia and the South Sandwich Islands MPA: protecting a biodiverse oceanic island chain situated in the flow of the Antarctic Circumpolar Current. Adv Mar Biol 69:15-78

Vamplew W (1975) Salvesen of Leith. Scottish Academic Press, Edinburgh

Watkins JL, Hewitt RP, Naganobu M, Sushin VA (2004) The CCAMLR 2000 survey: a multinational, multi-ship, biological oceanography survey of the Atlantic sector of the Southern Ocean. Deep Sea Res II 51:1205-1213

Submitted: June 23, 2020; Accepted: September 7, 2020

Proofs received from author(s): November 8, 2020 